\title{
Hyperthermia treatment can kill immature and adult Varroa destructor mites without reducing drone fertility
}

\author{
Arne Kablau ${ }^{1,2}$, Stefan Berg ${ }^{3}$, Stephan Härtel ${ }^{4}$, Ricarda Scheiner ${ }^{1}$ \\ ${ }^{1}$ Behavioral Physiology \& Sociobiology, University of Würzburg, Biocenter, Am Hubland, 97074, Würzburg, Germany \\ ${ }^{2}$ Department of Veterinary Medicine, Institute of Veterinary Biochemistry, Freie Universität Berlin, Berlin, Germany \\ ${ }^{3}$ Institute for Bee Research and Beekeeping, Bavarian State Institute for Viticulture and Horticulture, Veitshöchheim, \\ Germany \\ ${ }^{4}$ Animal Ecology \& Tropical Ecology, University of Würzburg Biocenter, Am Hubland, 97074, Würzburg, Germany
}

Received 8 January 2019 - Revised 5 October 2019 - Accepted 7 November 2019

\begin{abstract}
In the last few decades, different hyperthermia devices have been developed to kill Varroa destructor mites in the colony. Intriguingly, effects of hyperthermia on Varroa destructor and honeybee brood have hardly been investigated. We exposed honeybee brood to temperatures of $41^{\circ} \mathrm{C}$ to $45^{\circ} \mathrm{C}$ to investigate effects on Varroa destructor in the hive and on drone fertility of treated colonies. Drone fertility is an important issue in keeping healthy and viable honeybee populations. We show that temperatures of $42^{\circ} \mathrm{C}$ for 3 hours or higher kill all the Varroa destructor but, unfortunately, also part of the honeybee brood. Temperatures below $42^{\circ} \mathrm{C}$ are ineffective against adult Varroa destructor. A temperature of $41^{\circ} \mathrm{C}$ and 2 hours duration is highly effective against immature Varroa destructor and thus interrupts their reproduction without harming the viability or fertility of drones, while longer durations or higher temperatures kill the spermatozoa of the drones.
\end{abstract}

\section{Varroa destructor / Apis mellifera / Temperature / Sperm viability}

\section{INTRODUCTION}

The economic value of worldwide pollination is estimated to be 153 billion Euros per year (Gallai et al. 2009), because the 100 most important crops worldwide are pollinated by insects (Machado et al. 2004). More than $75 \%$ of global crops depend on pollination, from which $73 \%$ is performed by bees (Machado et al. 2004). Therefore, the honeybee is a major pollinator of agricultural crops worldwide.

In Germany, Varroa destructor was introduced in the 1970s (Ruttner 1977). In the last decades, heavy bee losses have been reported due to the

Corresponding author: A. Kablau, arne.kablau@fuberlin.de

Handling Editor: Yves Le Conte ectoparasitic mite Varroa destructor (Peng et al. 1987). There are four Varroa species known, but only Varroa destructor is found worldwide. The life cycle of Varroa destructor not only affects adult bees but also drone and worker brood. However, the infestation rate of drone brood is five to nine times higher than that of workers (Schulz 1984; Fuchs 1990). The infection with Varroa destructor, i.e., varroosis, does not only harm honeybees directly through a loss of fat tissue (Ramsey et al. 2019). The mite can also be a vector for different pathogens. Varroosis can thus lead to the deformation of abdomen or wings through transmission of the deformed wing virus (de Jong et al. 1982), can lead to a shortened lifetime (Schneider und Drescher 1987), and can result in secondary infestation by bacteria and viruses (Chen and Siede 2007). In addition, Varroa-infested nurse bees display reduced brood 
care, probably due to accelerated aging (Zanni et al. 2018).

Naturally, there is a great interest in methods to prevent Varroa destructor from growing and reproducing in honeybee colonies. Different methods have been suggested to reduce the number of mites in the hive. The most common ones are chemical applications like synthetic acaricides or organic acids (Rosenkranz et al. 2010). Nevertheless, there are several disadvantages of using chemicals in bee hives, like chemical residues in bee products (Wallner 1999), or the risk of sublethal effects in combination with pesticides (Williamson et al. 2013). Another problem lies in the fact that the mites can develop resistances (Elzen et al. 1998). Furthermore, investigations are under way to breed Varroa-tolerant bees (Büchler et al. 2010, Le Conte and Mondet 2017).

Besides chemical applications, there is also a physical approach that has become popular in the last decades: hyperthermia. Bees and mites differ in their sensitivity for rising temperatures (Engels 1998). Varroa females favor temperatures of $32^{\circ} \mathrm{C}$ or lower. Temperatures of $40^{\circ} \mathrm{C}$ or higher are lethal for the mites (Rosenkranz 1988). In contrast, honeybee larvae tolerate $2-3^{\circ} \mathrm{C}$ higher temperatures than the mites (Engels 1998). Hyperthermia is a method in which the complete bee hive or just the sealed brood combs are exposed to higher temperatures which are lethal for Varroa destructor but not for the bees. Several successful methods for effective hyperthermia treatment have been reported in the last decades (Ruttner 1977, Karpov and Zabelin 1978, Khrust 1978, Soloveva 1983, Hoppe and Ritter 1987, Le Conte et al. 1990, Huang 2001, Goras et al. 2015).

For application in the hive, there have been different hyperthermia devices on the market for some years now. All of them employ the same principle but differ in their application (Varroa Controller, Varroa Kill II, Bienensauna, miteZapper, Borgstadter-Themo-Box, Apitherm Box, Thermovar). Intriguingly, controlled experiments analyzing the effects of the different devices on honeybee brood are lacking. A number of experiments have addressed the effects of hyperthermia on Varroa mites and honeybee brood. Generally, it is highly important to maintain a constant brood temperature of about $35^{\circ} \mathrm{C}$. This homeostasis is accomplished by bees raising their thoracic temperature to up to $38^{\circ} \mathrm{C}$ and pressing their body onto the brood caps or by staying in empty cells for heat transfer (Bujok et al. 2002, Kleinhenz et al. 2003). Despite the narrow temperature tolerance of honeybee brood, Rosenkranz (1987) and Brodsgaard and Hansen (1994) showed that hyperthermia employed to kill the mites in sealed brood cells had only minor effects on the bee brood. Tarelho (1981), in contrast, incubated drone brood at $40-45^{\circ} \mathrm{C}$ for up to 1,280 minutes. Afterwards, brood mortality was increased. These findings suggest that drone brood might be much more sensitive to hyperthermia than worker brood. Even if the drones treated with hyperthermia as larvae survive, their sperm might not be as viable as that of untreated drones. Tarelho (1981) reported enlarged spermatocytes and testes after hyperthermia treatment. Stürup et al. (2013) exposed drones and ejaculates to $39^{\circ} \mathrm{C}$ for 4 hours and found decreased sperm viability. Koeniger et al. (2006) showed that drones that were reared at $36^{\circ} \mathrm{C}$ during pupal stage showed a decreased number of spermatozoa. Similarly, the results of Czekońska et al. (2013) indicate that higher temperatures decrease the number of living spermatozoa.

These findings show the need for controlled experiments on the effects of hyperthermia not only on worker bee brood and drone brood but also on the fertility of drones, which are important contributors to maintaining colony fitness (Pettis et al. 2016).

The aim of our study was therefore to investigate the effects of short-term hyperthermia on the viability of Varroa destructor mites as well as on the viability and fertility of drones.

\section{MATERIAL AND METHODS}

\subsection{Source of bees}

The experiments were performed in the summer of 2013 with colonies of Apis mellifera carnica. All colonies were maintained at the Bavarian State Institute for Viticulture and Horticulture, Institute for Bee Research and Beekeeping, Veitshöchheim, Germany. All colonies were in Zander hives $(420 \mathrm{~mm} \times 220 \mathrm{~mm})$ with one to 
two brood chambers (10 frames/box). Drone brood was taken from several colonies, and worker brood was reared in colonies with a high infestation rate of Varroa destructor.

\subsection{Hyperthermia treatment}

For our experiments, we used a Memmert IPP 500 incubator. After it had reached $35^{\circ} \mathrm{C}$, one brood comb was placed in the incubator, and temperature was steadily increased by $1^{\circ} \mathrm{C}$ per 5 minutes until the final temperature $\left(41^{\circ} \mathrm{C}, 42^{\circ} \mathrm{C}\right.$, $43^{\circ} \mathrm{C}$, or $45^{\circ} \mathrm{C}$ ) was reached. After this heating period, the treatment started for 2 or 3 hours. Humidity was hold constant at $70-90 \%$ by using water-filled glass bowls. Temperature and humidity were measured by a temperature and humidity device from Scanntronik Hygrofox.

\subsection{Drone treatment}

To accomplish a brood frame with three age cohorts of exclusively drone brood, we constructed three smaller frames and placed them in one Zander frame (Figure 1). First of all, the empty frames were placed in a colony to induce the worker bees to build drone brood cells. Afterwards, the first smaller frame was placed into the Zander frame and the queen was caged to lay eggs on it (age group 19). Three days and 6 days later, the other two frames were inserted into the Zander frame, and the queen was also caged for egg laying (age group 16 and age group 13). Twelve days later, the Zander frame containing the age cohorts was treated with hyperthermia. Afterwards, drone brood was restored to the hive. For statistical analyses, we treated two of our modified frames with three age cohorts at $41^{\circ} \mathrm{C}$ for 2 hours in two different colonies. At emergence, drones were prevented from comb leaving by placing in between queen excluders. They were marked according to their hatching date.

\subsection{Varroa destructor mortality}

Worker brood of different ages was treated with hyperthermia, and immediately afterwards, 24 hours and 48 hours later, 100 cells were randomly opened on one side of the frame to determine mortality of immature and adult Varroa destructor in the brood. We just opened 100 cells to prevent mass worker brood loss due to the experimental design. We did not record worker brood mortality. Number of treated worker brood frames for the different temperature regimes was the following: $41^{\circ} \mathrm{C} 2 \mathrm{~h} \mathrm{n}=6,41^{\circ} \mathrm{C} 3 \mathrm{~h} \mathrm{n}=2$, $42^{\circ} \mathrm{C} 2 \mathrm{~h} \mathrm{n}=2,42^{\circ} \mathrm{C} 3 \mathrm{hn}=3,43^{\circ} \mathrm{C} 3 \mathrm{~h} \mathrm{n}=1$, and $45^{\circ} \mathrm{C} 3 \mathrm{~h} \mathrm{n}=1$.

\subsection{Spermatozoa analysis}

Twelve days after hatching, marked drones were captured for spermatozoa analysis. Prior to dissection, drones were placed in the refrigerator for 30 minutes to decrease their activity and to prevent a premature ejaculation due to decapitation. After opening the abdomen, the mucous glands and vesiculae seminalis were placed into glycine buffer solution (0.1 M, pH 8.6). Mucous glands were removed and vesiculae seminalis were comminuted to mix the spermatozoa with the buffer. A droplet was placed under a microscope to estimate the percentage of living spermatozoa (spermatozoa motility). Afterwards, the spermatozoa/buffer solution was mixed with water to kill the spermatozoa, and after that, $2 \times 5$ group squares of a Neubauer-improved counting chamber (WHO, 1999) were used to estimate the spermatozoa number. We analyzed a total of 103 drones (hyperthermia 13 days: 18; 16 days: $21 ; 19$ days: 16; control 13 days: 15; 16 days: 18; 19 days: 15).

\subsection{Statistics}

Mortality of adult female Varroa destructor mites and of immature mites was compared between groups using univariate analysis of variance with Fisher's least significant difference post hoc test (SPSS 24, IBM@ Armonk, New York, USA). Spermatozoa motility was quantified using a Neubauer-improved counting chamber. The percentage of moving spermatozoa in a droplet of spermatozoa solution was estimated. Spermatozoa motility of all age cohorts was not distributed normally $(\mathrm{P}<0.001$, Kolmogorov-Smirnov test) and was therefore compared between hyperthermia-treated drones and control drones 


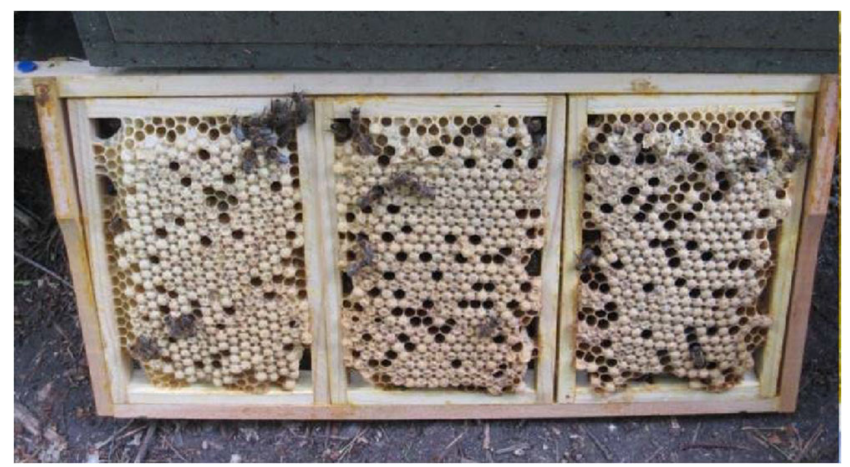

Figure 1. Zander frame with three small frames to get a brood frame with three age cohorts of exclusive drone brood.

using Mann-Whitney U tests. Spermatozoa number was analyzed using a Neubauer-improved counting chamber. Spermatozoa number of all age cohorts was distributed normally $(\mathrm{P}>0.05$, Kolmogorov-Smirnov test) and was therefore compared between two groups using t-tests. We excluded data from temperatures higher than $42^{\circ} \mathrm{C}$ because bee brood completely died.

\section{RESULTS}

\subsection{Mortality of adult Varroa destructor mites}

At all times, hyperthermia treatment had a significant effect on the mortality of adult Varroa destructor females $\left(0 \mathrm{~h}: \mathrm{F}_{(5,9)}=56.80, \mathrm{P}<\right.$ 0.001, 24 h: $\mathrm{F}_{(3,7)}=48.53, \mathrm{P}<0.001,48 \mathrm{~h}: \mathrm{F}_{(3,8)}$ $=109.18, \mathrm{P}<0.001)$. Hyperthermia treatment at $41^{\circ} \mathrm{C}$ for 2 or 3 hours as well as treatment at $42^{\circ} \mathrm{C}$ for $2 \mathrm{~h}$ resulted in a very low adult Varroa destructor mortality directly after treatment (Figure 2). These treatment groups did not differ from each other in the resulting mortality of adult Varroa destructor $(\mathrm{P}>0.05)$. However, hyperthermia treatment at $42^{\circ} \mathrm{C}$ for 1 more hour (i.e., for 3 hours) already increased adult Varroa mortality drastically compared to the other treatments with lower temperature or shorter treatment durations $\left(42^{\circ} \mathrm{C}, 3 \mathrm{~h}\right.$ vs. $41^{\circ} \mathrm{C}, 2 \mathrm{~h}, \mathrm{P}<0.001 ; 42^{\circ} \mathrm{C}, 3 \mathrm{~h}$ vs. $41^{\circ} \mathrm{C}, 3 \mathrm{~h}, \mathrm{P}<0.001 ; 42^{\circ} \mathrm{C}, 3 \mathrm{~h}$ vs. $42^{\circ} \mathrm{C}, 2 \mathrm{~h}, \mathrm{P}<$ $0.001)$. Higher temperatures $\left(43^{\circ} \mathrm{C}\right.$ or $\left.45^{\circ} \mathrm{C}\right)$ reliably killed adult Varroa destructor but also killed the entire drone brood (data not shown). The effects of these treatments on adult Varroa destructor did not differ significantly from that of $42^{\circ} \mathrm{C} 3 \mathrm{~h}$. Therefore, we did not conduct any more experiments using hyperthermia with temperatures above $42^{\circ} \mathrm{C}$. In further counts of adult Varroa destructor at 24 hours and 48 hours after treatment, hyperthermia treatment of $42^{\circ} \mathrm{C}$ for 3 hours even killed $100 \%$ of the adult mites, whereas lower temperatures or a shorter treatment duration than 3 hours at $42^{\circ} \mathrm{C}$ was largely ineffective against adult mites ( 24 hours after treatment: $42^{\circ} \mathrm{C}, 3 \mathrm{~h}$ vs. $41^{\circ} \mathrm{C}, 2 \mathrm{~h}, \mathrm{P}<0.001 ; 42^{\circ} \mathrm{C}, 3 \mathrm{~h}$ vs. $41^{\circ} \mathrm{C}, 3 \mathrm{~h}, \mathrm{P}<0.001 ; 42^{\circ} \mathrm{C}, 3 \mathrm{~h}$ vs. $42^{\circ} \mathrm{C}, 2 \mathrm{~h}, \mathrm{P}<$ $0.001 ; 48$ hours after treatment, $42^{\circ} \mathrm{C}, 3 \mathrm{~h}$ vs. $41^{\circ} \mathrm{C}, 2 \mathrm{~h}, \mathrm{P}<0.001 ; 42^{\circ} \mathrm{C}, 3 \mathrm{~h}$ vs. $41^{\circ} \mathrm{C}, 3 \mathrm{~h}, \mathrm{P}$ $<0.001 ; 42^{\circ} \mathrm{C}, 3$ h vs. $\left.42^{\circ} \mathrm{C}, 2 \mathrm{~h}, \mathrm{P}<0.001\right)$. At temperatures of $42^{\circ} \mathrm{C}$, damage on young larvae was observed (e.g., no movement or bursted bodies).

\subsection{Mortality of immature Varroa destructor mites}

Immature mites (Figure 3) were much more sensitive to hyperthermia. Immediately after hyperthermia treatment, more than $80 \%$ of immatures died in all treatment groups. At temperatures above $42^{\circ} \mathrm{C}$, even $100 \%$ of the immature mites were dead (data not shown). Therefore, we did not analyze effects of temperatures above $42^{\circ} \mathrm{C}$ on the following 2 days. Higher temperatures $\left(43^{\circ} \mathrm{C}\right.$ and $45^{\circ} \mathrm{C}$ ) also reliably killed the honeybee brood (data not shown).

Mortality increased to almost $100 \%$ on day 2 and to $100 \%$ on day 3 when bees were treated at $41^{\circ} \mathrm{C}$ (Figure 3). It remained at 

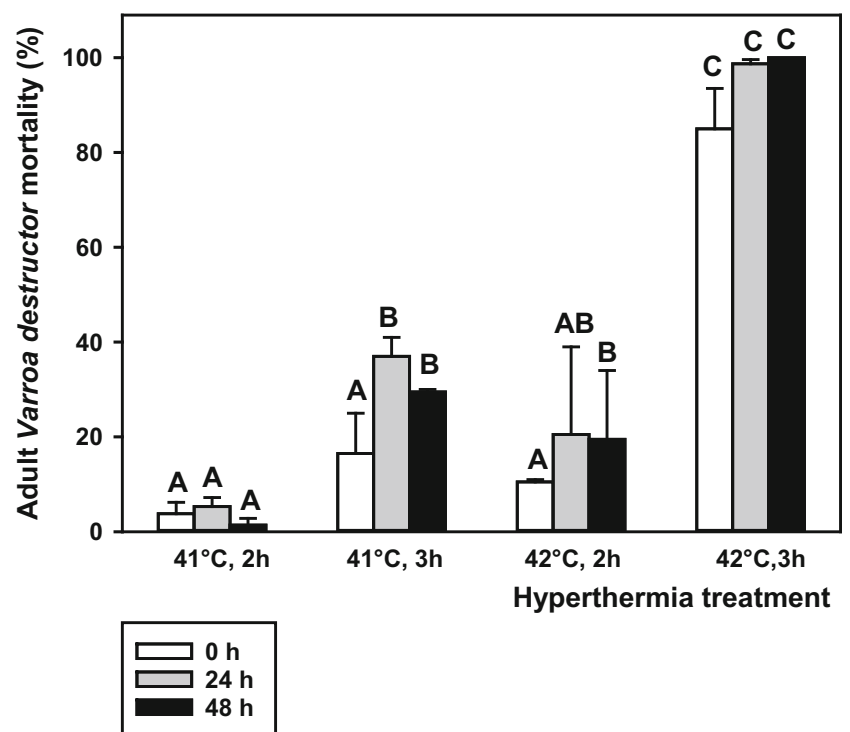

Figure 2. Mean mortality of adult Varroa destructor and standard errors of the mean. At three time points after treatment, adult Varroa destructor mortality was quantified. Significant differences between groups are indicated by different letters $(\mathrm{P}<0.001)$. We recorded a total of 2,403 adult Varroa destructor.

$100 \%$ at temperatures higher than $41^{\circ} \mathrm{C}$ (Figure 3). There was no significant difference between the exposition times (two or three hours) at $41^{\circ} \mathrm{C}$ or at $42^{\circ} \mathrm{C}\left(41^{\circ} \mathrm{C}: \mathrm{P}>0.05\right.$; $\left.42^{\circ} \mathrm{C}: \mathrm{P}>0.05\right)$.
Because a treatment of $41^{\circ} \mathrm{C}$ for 2 hours showed no visual damage of the drone brood, while effectively reducing the number of immature mites (Figure 3), we selected this temperature regime for further analyses of drone fertility.

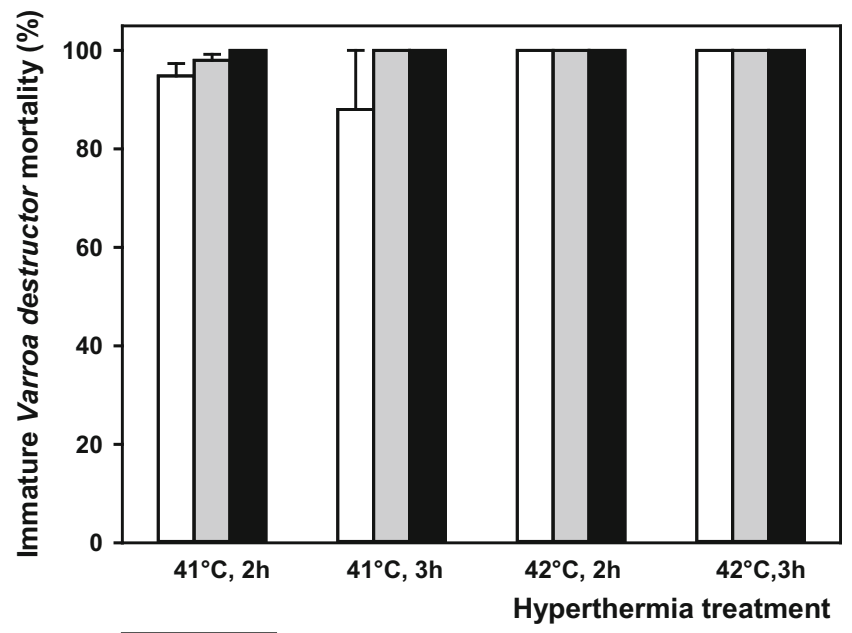

Figure 3. Mean mortality of immature Varroa destructor (\%) and standard errors of the mean. At three time points after treatment, immature Varroa destructor mortality was analyzed. We recorded a total of 1,268 immature Varroa destructor. 


\subsection{Effects of hyperthermia on spermatozoa}

Drones of known age were tested for their spermatozoa motility (Figure 4A). There was no significant difference in the proportion of motile spermatozoa between the control groups and hyperthermia-treated groups on day $13\left(\mathrm{n}_{\text {control }}=15, \mathrm{n}_{\text {hyperthermia }}=18 ; \mathrm{P}>\right.$ $0.05)$, on day $16\left(\mathrm{n}_{\text {control }}=18, \mathrm{n}_{\text {hyperthermia }}=\right.$ 21; $\mathrm{P}>0.05)$, and on day $19\left(\mathrm{n}_{\text {control }}=15\right.$, $\mathrm{n}_{\text {hyperthermia }}=16 ; \mathrm{P}>0.05$, Mann Whitney $\mathrm{U}$ test) after treatment. These data suggest that this temperature regime has no negative effects on drone spermatozoa motility. There was also no significant effect of hyperthermia treatment on spermatozoa numbers at day $13\left(\mathrm{n}_{\text {control }}=\right.$ $\left.15, \mathrm{n}_{\text {hyperthermia }}=18 ; \mathrm{P}>0.05\right)$, day $16\left(\mathrm{n}_{\text {control }}\right.$ $\left.=18, \mathrm{n}_{\text {hyperthermia }}=21 ; \mathrm{p}=0.965\right)$, and day 19 $\left(\mathrm{n}_{\text {control }}=15, \mathrm{n}_{\text {hyperthermia }}=16 ; \mathrm{p}=0.525, \mathrm{t}-\right.$ test) (Figure 4B).

\section{DISCUSSION}

Our data suggest a closely linked temperature tolerance of Varroa destructor and that of their host, the honeybee (Apis mellifera). Hyperthermia treatment using temperatures above $42^{\circ} \mathrm{C}$ reliably killed both adult and immature mites, similar to what has been shown by Goras et al. (2015). Unfortunately, these high temperatures also killed the drone brood. Therefore, this treatment is unsuitable for removing Varroa destructor from a honeybee colony.

Treatment at $41^{\circ} \mathrm{C}$ for 2 hours effectively killed immature Varroa destructor while not affecting drone vitality or fertility. Thus we can effectively interrupt the reproductive cycle of Varroa destructor without harming honeybee drones. We therefore recommend this temperature regime as an effective treatment of hives against Varroa destructor.
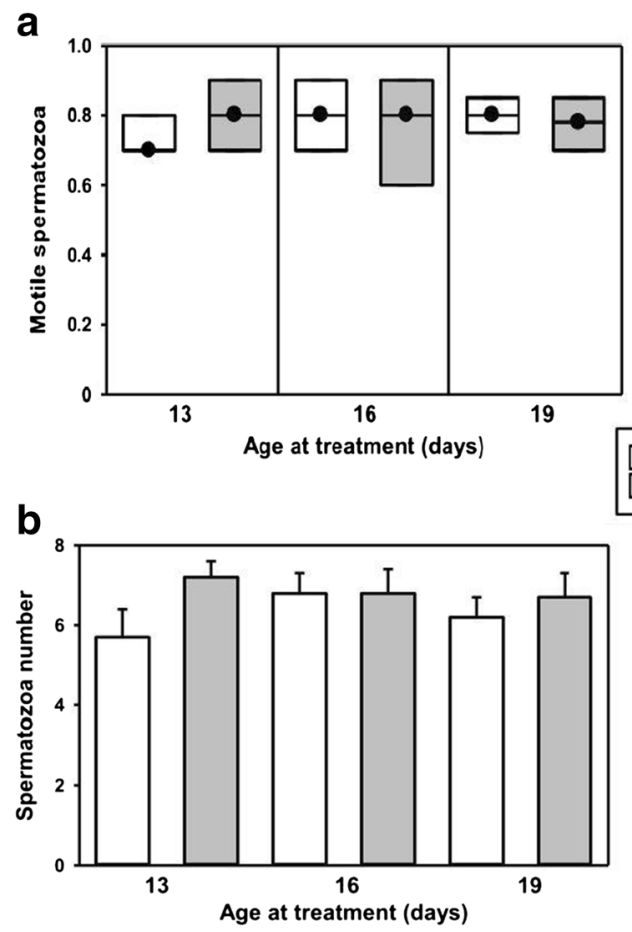

Figure 4. Median sperm motility (dots) and quartiles (upper and lower lines) (A) and mean sperm number in millions and standard errors of the means (B) after hyperthermia treatment of drones at $41^{\circ} \mathrm{C}$ for 2 hours. We tested a minimum of 15 drones per group. 
The decisive advantages of hyperthermia treatment, in contrast to chemical acaricides, are no residues in bee products, application throughout the year - even during honey flow season - and no chemical exposition of the bees. Especially, formic acid might lead to an increased mortality of brood (Bolli et al. 1993), workers, or queens (VonPosern 1988).

Although our experiments did not detect any negative effect on drone brood or spermatozoa after this treatment $\left(41^{\circ} \mathrm{C}, 2 \mathrm{~h}\right)$, it is an important question whether this treatment has any negative effect on female honeybee brood and workers. Fully developed workers with normal life span are an important part of a functional honeybee colony. Tarelho (1981) earlier investigated the impact of hyperthermia on female honeybees when hyperthermia treatment was performed over the whole pupae stages. He used pre-pupae (13 days old) and pupae (15 days old) for his experiments. The brood was incubated at $40^{\circ} \mathrm{C}$ or $45^{\circ} \mathrm{C}$ for five different time intervals up to 20 hours. Both temperatures led to increased mortality. At $40^{\circ} \mathrm{C}$, pre-pupae showed a faster metamorphosis. At $45^{\circ} \mathrm{C}$, pre-pupae showed chromosome aberrations. Le Conte et al. (1990) further showed that temperatures higher than $37.5^{\circ} \mathrm{C}$ decreased the fertility and furthermore temperatures higher than $38.5^{\circ} \mathrm{C}$ increased mortality of adult mites to $100 \%$. Goras et al. (2015) used a heating device to increase the temperature of the bee hive to $42^{\circ} \mathrm{C}$ for up to 480 minutes. They noticed a higher brood mortality after 240 minutes. An adequate mortality rate of adult female mites (92\%) was reached after 360 minutes, whereas we just needed 180 minutes to reach $100 \%$. One reason for these differences might be that Goras et al. measured the temperature of the air but not of the brood itself. That, however, is the crucial point for a successful application. Another reason could be the fact that they treated the whole bee hive. Adult bees are able to cool the brood through actively evaporating water, ventilation, or oxidizing carbohydrates (Komissar 1985). Kreuzpainter et al. (2016) showed that at temperatures of $42-45^{\circ} \mathrm{C}$ and an exposition time of 1-2 hours, the number of eggs laid afterwards was significantly reduced. Intriguingly, Tautz et al. (2003) showed that temperatures of $36^{\circ} \mathrm{C}$ led to better dance and learning performance in honeybees. Groh et al. (2004) further showed that temperature differences deviating only $1{ }^{\circ} \mathrm{C}$ from optimal brood temperature caused a decrease in the number of microglomeruli in the lip of the mushroom bodies. The microglomeruli are distinct synaptic complexes in the mushroom body calyx subregions and play a major role in memory consolidation and synaptic plasticity (Hourcade et al. 2010). It could be shown that during the transition from nurse bees to foragers, the volume of the calyces increases (Fahrbach und Dobrin 2009) while the number of microglomeruli decreases (Muenz et al. 2015). All these data suggest that hyperthermia treatment might have effects on worker brood development and adult behavior, but more studies are needed to clarify in how far short-term hyperthermia treatment affects worker bees.

Similarly, experiments on longevity need to be performed in worker bees and queens which had undergone Varroa treatment using hyperthermia.

\section{CONCLUSION}

Based on our experimental findings with drones, we suggest a hyperthermia treatment of $41^{\circ} \mathrm{C}$ and 2 hours duration for safely reducing immature Varroa destructor and thus interrupting the mite's reproductive cycle. Effects of this treatment on worker brood and adults still need to be determined.

\section{ACKNOWLEDGMENTS}

We like to thank all of the beekeepers at the Bavarian State Institute for Viticulture and Horticulture, Institute for Bee Research and Beekeeping for their great support and for providing us with the colonies.

Contributions $\mathrm{AK}, \mathrm{SB}$, and $\mathrm{SH}$ conceived this research and designed experiments; RS participated in the interpretation of the data; AK performed experiments; AK and RS wrote the paper. All authors read the manuscript. 


\section{COMPLIANCE WITH ETHICAL STANDARDS}

Conflict of interest The authors declare that they have no conflict of interest.

Le traitement par hyperthermie peut tuer les acariens Varroa destructor immatures et adultes sans réduire la fertilité des mâles.

Varroa destructor / Apis mellifera / température / viabilité du sperme.

Hy perth e r mi e-B e hand lungen können Entwicklungsstadien und adulte Milben von Varroa destructor töten ohne die Drohnenfertilität zu reduzieren.

\section{Varroa destructor / Apis mellifera / Temperatur /} Spermienvitalität.

\section{REFERENCES}

Brodsgaard C.J., Hansen, H. (1994) An example of integrated biotechnical and soft chemical control of Varroa in a Danish apiary. In: Matheson A. (ed.): New Perspectives on Varroa, pp. 101-105.

Büchler R., Berg S., Le Conte Y. (2010) Breeding for resistance to Varroa destructor in Europe, Apidologie 41, 393-408.

Bolli H. K., Bogdanov S., Imdorf A., Fluri P. (1993) Action of formic acid on Varroa jacobsoni Oud. and the honeybee (Apis mellifera L ), Apidologie 24, 1, 51-57.

Bujok B., Kleinhenz M., Fuchs S., \& Tautz J. (2002) Hot spots in the bee hive, Naturwissenschaften 89, 7, 299301.

Chen Y. P., Siede R. (2007) Honey bee viruses, Adv. Virus Res. 70, 33-80.

Czekońska K., Chuda-Mickiewicz B., \& Chorbiński P. (2013) The effect of brood incubation temperature on the reproductive value of honey bee (Apis mellifera) drones, J. Apic. Res. 52, 2, 96-105.

Elzen P. J., Eischen F. A., Baxter J. B., Pettis J., Elzen G. W., Wilson W. T. (1998) Fluvalinate resistance in Varroa jacobsoni from several geographic locations, Am Bee J 138, 9, 674-676.

Engels W. (1998) Efficiency of Biotechnical Control of Varroasis by means of Hyperthermia, Apiacta 33, 2, 49-55.
Fahrbach S. E., Dobrin S. (2009) The How and Why of Structural Plasticity in the Adult Honeybee Brain, in: Dukas R., Ratcliffe J. M. (Ed.), Cognitive ecology II. University of Chicago Press, Chicago, pp. 27-46.

Fuchs S. (1990) Preference for drone brood cells by Varroa jacobsoni Oud in colonies of Apis mellifera carnica, Apidologie 21, 3, 193-199.

Gallai N., Salles J.-M., Settele J., Vaissière B.E. (2009) Economic valuation of the vulnerability of world agriculture confronted with pollinator decline, Ecol. Econ. $68,3,810-821$.

Goras G., Tananaki C.H., Gounari S., Dimou M., Lazaridou E., Karazafiris E., Kanelis D., Liolios V., El Taj H.F., Thrasyvoulou A. (2015) Hyperthermia -a non-chemical control strategy against Varroa, J Hell Vet Med Soc 66, 4, 249-256.

Groh C., Tautz J., Rössler W. (2004) Synaptic organization in the adult honey bee brain is influenced by broodtemperature control during pupal development, P Natl Acad Sci 101, 12, 4268-4273.

Hoppe H., Ritter W. (1987) Experiments using combined heat therapy to control Varroa disease, Apidologie 18, 383-385.

Hourcade B., Muenz T.S., Sandoz J.-C., Rössler W., Devaud J.-M. (2010) Long-term memory leads to synaptic reorganization in the mushroom bodies. A memory trace in the insect brain?, J Neurosci 30, 18, 64616465.

Huang Z. (2001) Mite zapper-a new and effective method for Varroa mite control, Am Bee J 141, 10, 730-732.

de Jong D., de Jong P.H., Goncalves L.S. (1982) Weight loss and other damage to developing worker honeybees from infestation with Varroa jacobsoni, J. Apic. Res. 21, 3, 165-167.

Karpov B., Zabelin B. (1978) Heat treatment for the control of Varroa jacobsoni infestation in bees [in Russian], Veterinariya Moscow 5, 121-122.

Khrust I. I. (1978) Thermal treatment during Varroatosis [in Russian], Pchelovodstvo 6, 5-8.

Kleinhenz M., Bujok B., Fuchs S., \& Tautz J. (2003) Hot bees in empty broodnest cells: heating from within, $\mathrm{J}$. Exp. Biol. 206, 23, 4217-4231.

Koeniger G., Ziegler-Himmelreich S., Koeniger N. (2006) Spermatozoa number of drones (Apis mellifera) depends on temperature during metamorphosis and sexual maturation, Apidologie 37, 620-621.

Komissar A.D. (1985) Heat-treatment of Varroa-infested honeybee colonies, Apiacta 20, 4, 113-117.

Le Conte Y., Arnold G., Desenfant P. (1990) Influence of brood temperature and hygrometry variations on the development of the honey bee ectoparasite Varroa jacobsoni (Mesostigmata: Varroidae), Environ. Entomol. 19, 6, 1780-1785.

Le Conte Y., Mondet F. (2017): Natural Selection of Honeybees Against Varroa destructor, in: Vreeland R., Sammataro D. (Ed.), Beekeeping - From Science to Practice, Springer, Cham. 
Machado I. C., Freitas B.M., Pereira J.O.P. (2004) Solitary bees. Conservation, rearing and management for pollination, Brazil. Universidade Federal do Ceará

Muenz T. S., Groh C., Maisonnasse A., Le Conte Y., Plettner E., Rössler W. (2015) Neuronal plasticity in the mushroom body calyx during adult maturation in the honeybee and possible pheromonal influences, Dev Neurobiol 75, 12, 1368-1384.

Peng Y.-S., Fang Y., Xu S., Ge L. (1987) The resistance mechanism of the Asian honey bee, Apis cerana Fabr., to an ectoparasitic mite, Varroa jacobsoni Oudemans, J Invertebr Pathol 49, 1, 54-60.

Pettis J.S., Rice N., Joselow K., vanEngelsdorp D., Chaimanee V. (2016) Colony failure linked to low sperm viability in honey bee (Apis mellifera) queens and an exploration of potential causative factors,Plos One 11.

Ramsey S. D., Ochoa R., Bauchan G., Gulbronson C., Mowery J. D., Cohen A., Lim D. Joklik J., Cicero J. M., Ellis J. D., Hawthorne D., vanEngelsdorp D. (2019) Varroa destructor feeds primarily on honey bee fat body tissue and not hemolymph, PNAS 116, $5,1792-1801$.

Rosenkranz P. (1987): Apidologie 18, 4, 385-388

Rosenkranz P. (1988) Temperaturpräferenz der VarroaMilbe und Stocktemperaturen in Bienenvölkern an Tropenstandorten (Acarina: Varroidae/Hymenoptera: Apidae), Entomologia Generalis 14, 2, 123-132.

Rosenkranz P., Aumeier P., Ziegelmann B. (2010) Biology and control of Varroa destrutor, J. Invertebr. Pathol. 103, 96-119

Ruttner H. (1977) Die Milbe Varroa jacobsoni Oudem., ein neuer Bienenparasit, J Pestic. Sci. 50, 11, 165-169.

Schneider P., Drescher W. (1987) The influence of Varroa jacobsoni Oud. on weight at emergence, development of weight and hypopharyngeal glands, and longevity of Apis mellifera L, Apidologie 18, 1, 101-110.
Schulz A. E. (1984) Reproduktion und Populationsentwicklung der parasitischen Milbe Varroa jacobsoni Oud. in Abhängigkeit vom Brutzyklus ihres Wirtes Apis mellifera L. (I. TEIL), Apidologie 15, 4, 401-420.

Soloveva L. F. (1983) Thermal treatment to control Varroa disease of honeybees [in Russian], Pchelovodstvo 1, 17-18.

Tarelho Z. (1981) Effects of low and high temperatures on the spermathogenesis of Apis mellifera L, Revista Brasilera de Genetica 4, 193-212.

Tautz J., Maier S., Groh C., Rössler W., Brockmann A. (2003) Behavioral performance in adult honey bees is influenced by the temperature experienced during their pupal development, P Natl A Sci 100, 12, 7343-7347.

VonPosern H. (1988) Stopping Varroa victory march, Am Bee Jo 128, 6, 425-428.

Wallner K. (1999) Varroacides and their residues in bee products, Apidologie 30, 2-3, 235-248.

WHO (1999) WHO laboratory manual for the examination of human semen and sperm-cervical mucous interaction, Cambridge University Press.

Williamson S.M., Baker D.D., Wright G.A. (2013) Acute exposure to a sublethal dosis of imidacloprid and coumaphos enhances olfactory learning and memory in the honeybee Apis mellifera, Invertebr. Neurosci. 13, 1, 63-70.

Zanni V., Degirmenci L., Annoscia D., Scheiner R., Nazzi F. 2018 The reduced brood nursing by mite infested honey bees depends on their accelerated behavioral maturation, J. Insect Physiol. 109, 47-54.

Publisher's note Springer Nature remains neutral with regard to jurisdictional claims in published maps and institutional affiliations. 